\title{
The Veracious Construal of Halal Cosmetic Products and its Relation to Taharah (Cleanliness) and Nadhafah (Hygiene and Sanitation) in Islam
}

\author{
Abdi O. Shuriye PhD \\ Department of Science, Faculty of Engineering, IIUM
}

Doi:10.5901/mjss.2015.v6n6s1p266

\begin{abstract}
Cosmeticology is the science of cosmetics and related products; hence, cosmetic refers to any preparation applied to any parts of the human body with the intention of beautification, enhancing its performance, or appraising its functions. Therefore, cosmetic is directly related to the physical and emotional health as well as conditions of human skin and body. While the experience and the knowledge of the cosmeticologists and dermatologists are vital in cosmetic use and its production, it is equally imperative to evaluate cosmetic products from the perspective of human life and values. Thus, cosmetic activities are related to our faith, dignity and spirituality as the halalness, hygiene and purity of what is consumed are part of human values. The objective of this research is to provide accurate conception of halal cosmetic products as well as to redefine the idea of cleanliness in line with the current circumstances of human economic activities. On the theoretical concept of the research, the theoretical apparatus of this paper is to link taharah (cleanliness) to nadhafah (hygiene and sanitation) so as to present taharah as part of both physical and spiritual aspects of the human. It is unfortunate that in the current conception of a Muslim taharah is presented as it has to do with religiosity and place of worship; this conception of taharah eliminates the concepts of nadhafah (hygiene and sanitation). The idea is that if one is wearing the same dress for five conservative days without a contact of filth (najis) it is considered in Islam tahir (clean). On the contrary, the paper suggests that if something lacks hygiene i. e. it smells or tastes bad or hazardous, be it place, dress or food it automatically becomes unhygienic to human and subsequently should be considered harmful regardless of whether or not it had any contact with filth (najis). Therefore, both taharah and nadhafah are directly related to halal.The research refers to the original sources of Islam including the Qur'an and the Hadith of the Prophet. Research questions include what is the constituent of halal and taharah (cleanliness) in relation to cosmetic products? To accomplish this research, library based methodology will be employed. With this methodology we will evaluate the available resources to determine the corollary of the issue at hand. The significance of this research lies in the fact that it reevaluates the quasi-laws of Islam which govern cosmetic products and its relevance to heath, hygiene and faith. The researcher is of the opinion that, this work will help the industry players, individuals and business communities.
\end{abstract}

\section{Introduction}

At the threshold of this discussion it is intellectually vivacious to further brighten that committed Muslims are too concern about the halalness of a product for it has a link to the core of the faith they adhere to, their religiosity, dignity and their spirituality as an entity in a social mass. Hence, the consumption attitude of a Muslim is shaped up by the purity or the filthiness of a product from religious standpoint. As a matter of fact, the term Halal which means lawful in the general will of God (the revealed guidelines from God) does not in any way refer only to food products or beverages as erroneously perceived by many consumers. In fact, anything which is harmful to human health or hazardous to the faith or corrupts the healthy way of thinking is haramized by the same general will of God. Therefore, the term halal must always be read together with, and in association with hygiene, sanitary and health in all aspects of human activities and life. It also signifies purity, unpolluted state of the product, and free from irregularities in manufacturing process.

\section{Literature Review}

The Qur'an is an essential religious, social and economic manuscript for Muslims. It is a divine guidance for mankind, and the final revelation from God. Besides, the Qur'an is the principal source of laws including regulations on halal matters. Therefore it reminds Muslims to consume pure. The Qur'an reads: "O you People! Eat of what is on earth, Halal and pure, and do not follow the footsteps of the Satan; Indeed for he is to you an open enemy" (al-Qur'an 2:168). On the above verse ibn Kathir said: "... He has allowed them to eat any of the pure lawful things on the earth that do not cause harm to the body or the mind...", (Tafsir ibn Kathir). While tafsir Jalalayn recorded that: "The following was revealed when some said that it was unlawful to take a camel that has been let loose: O people eat of what is in the earth, lawful (halalan is a circumstantial qualifier) and wholesome (tayyiban is an adjective for emphasis), that is to say, what is delicious..." (tafsir 
Jalalyn)

In a related verse Allah says: "O you who believe! Eat of the good things that We have provided for you and be grateful to Allah, if it is Him that you worship" (al-Qur'an 2:172). On a similar message, the Qur'an forbids Muslims carrion and other animals which are not slaughtered in His name: "Forbidden to you are Maytah (carrion or dead animal, animal not slaughtered with Tasmiyah i.e. reciting 'Bismillahi Allahu Akbar', flowing blood, the flesh of swine, and that slaughter on which was invoked name other than Allah, as well as the (animal) killed by strangulation or beaten to death with violent blow or falling (from a height) to its death or gored to death (through fighting) or by falling to a predator (and about to be consumed) -- unless you are able to slaughter in the name of Allah (swt) and carry out the sacrifice before it dies" (al-Qur'an, 5:3). The Qur'an therefore encouraged Muslims to consume halal and pure food. Allah says: "So eat of the lawful (Halal) and good food (Pure) which Allah has provided for you. And be grateful for the Graces of Allah, if it is He whom you worship (al-Qur'an, 16:114).

In the hadith of the Prophet we read similar laws and encouragements to consume halal and avoid doubtful things. The Prophet says: "Halal (the Lawful \& Permissible) is clear and Haram (the Unlawful \& Impermissible) is clear. Between halal and haram lays some doubtful things. Many people do not know whether it is permissible or not. Whoever leaves out these doubtful things in order to protect his religion and honor, then he is safe. Whoever indulges in these doubtful things/matters it is very possible that he will fall into haram, similar to a person who grazes his animals near the royal pasture it is very possible that one day he will graze in the royal pasture. Behold! Every king has a royal pasture and the royal pasture of Allah is those things which have been made impermissible." (at-Tirmidhi).

The Prophet also said: "Allah the Almighty is pure and accepts only that which is pure". (Muslim). In a similar hadith the Prophet said: "Avoid whatever you have doubts about in favor of what is not (doubtful)." (at-Tirmidhi). Another hadith reminds us that: "A body nourished with haram will not enter Jannah". (at-Tirmidhi). The Prophet also reminded Muslims to purify their food so that their du'a (supplication) is accepted. The Prophet said: "O S'ad purify your food (and as a result) you will become one whose supplications are accepted. I swear by Him in whose hands the soul of Muhammad lies, verily a servant (of Allah) tosses a haram (impermissible) food morsel in his stomach (due to which) no good deed is accepted from him for 40 days" (at-Tirmidhi).

The Qur'an and Hadith cover the subject generically while the rest of the literature concentrated on diverse areas including the market side of halal products and certification. In a paper entitled Assessing Halalan-Toyyiban Food Supply Chain in the Poultry Industry, Emi Normalina Omara et. al. covers Halalan Toyyiban supply chain, and the consumption of halal food. The paper argues that: "The consumption of halal food is becoming significant as it associates with quality, cleanliness and safety as underlines by the syariah principles" (Emi Normalina Omara et. al. 2012). More so, the concept of Halal is not only restricted to the issue of eating and drinking, on this Al-Jallad explains:

\begin{abstract}
"...the word Halal usually refers to food that is permissible according to Islam. However, in Arabic, it refers to permissible behavior, speech, dress, conduct, manner and dietary. In western countries, the term is usually used in the context of just Muslim food laws, especially where meat and poultry are concerned. In a Muslim's life, every aspect of life is regulated by Islamic law; therefore, the Halal-Haram dichotomy almost always applies to everything, and Muslims make sure they understand what is what since saying or doing al-Halal will lead to Paradise and al-Haram to "Hell." (AlJallad, 2008)
\end{abstract}

One of the major reasons why halal consumption is imperative in Islam is to preserve the sacredness and purity of the religion. This is because Islam is pure religion with a pure source and Muslims are supposed to maintain the purity of this religion, based on this, they are commanded not to bring about impurity to the religion. Equally, consumption of halal product as prescribed by Islam will assist in safeguarding the Islamic mentality; it is believed that, unlawful consumption of product corrupt human mind, this is because, eating and consuming unlawful products taints human soul. In fact, the consumption of unlawful products usually creates lack of peace and calmness to the mind and soul. (Rahman, 2009).

Equally, Islam prohibits unlawful consumption in order to preserve life. The word halal in Islamic sense is comprehensive and comprises cleanliness, quality and safety (Omar, Jaafar, \& Osman; 2012). Based on this, Muslim are commanded to consume halal product in order to live a healthy life (Yousef, 2010). In the same vein Allah commanded: "And spend in the cause of Allah and do not cause destruction for yourself, and do good deeds truly Allah loves the gooddoers" (al-Qur'an, 2:195). Similarly, preventing unlawful consumption in Islam brings about preservation of property and encourages mankind to maintain self-respect and dignity (Ahmad, 2008).

Therefore, certification of halal products is significant; and for that reason some of the literature underlines the issue. Kambiz Heidarzadeh Hanzaee and Mohammad Reza Ramezani in their work entitled Intention to Halal Products in the World Markets have contended that: "There are two types of halal certificates, and their duration depends on the type of food or beverage" (Kambiz Heidarzadeh Hanzaee and Mohammad Reza Ramezani, 2011). 
Motivating study prepared by Nor Ardyanti et. al., entitled: A Study on Halal Food Awareness among Muslim Customers in Klang Valley is worth reference. Authors of this study have embarked on Halal food consumption, government vision as a global halal hub and food outlet preferences among Muslim customers in Klang Valley. In a Similar work Sharifah Zannierah Syed Marzuki et. al., investigated the attitudes of restaurant managers in relation to halal certification in Malaysia. In a research entitled Restaurant managers' perspectives on halal certification, they studied managerial issues in restaurant service and certification advocates. The finding of this research is that certification is important in the halal industry. (Sharifah Zannierah Syed Marzuki et. al., 2011).

The current trend amongst manufacturers towards halal products was analyzed in the work of Rosita Husain, et al. The research concluded that the demand for halal cosmetics increases as there exists an increase in global demand for Halal products. The same research confirms that the modern trend amongst manufacturers tend towards certification and documentation. An implementation of statistical quality control and improvement techniques as methods of improving the quality of halal cosmetic in order to bring about the tayyiban concept was proposed. (Rosita Husain, et al., 2012).

\title{
3. Cleanliness and Halal Cosmetic Products in Islam
}

Cosmetic as a term has originated from the Greek kosmētikos meaning skilled in adornment. It also means to arrange and adorn. According to the English dictionaries the first known use of the word was in 1638. The term has its relation to beauty especially of the complexion, but it also could refer to correcting defects especially on the face. (Merriam-Webster) In conventional day-to-day usage cosmetic refers to substances used to enhance the appearance of the human body. Similarly the word pharmaceutics is from the Greek pharmakeutikos meaning to administer drugs; it has to do with also with manufacturing drugs. It is in fact, chemical substances formulated as single active ingredient. According to Standard procedures developed by UAE Technical Committee for Halal Cosmetic, the term covers:

\begin{abstract}
"Any substance or mixture intended to be placed in contact with the external parts of the human body (epidermis, hair system, nails, lips and external genital organs) or with the teeth and the mucous membranes of the oral cavity with a view exclusively or mainly to cleaning them, perfuming them, changing their appearance, protecting them, keeping them in good condition or correcting the body odors". (UAE Technical Committee for Halal Cosmetic)
\end{abstract}

Although some of the products may have been derived from natural sources others are mixtures of chemicals. The U.S., Food and Drug Administration (FDA) defines cosmetics as "intended to be applied to the human body for cleansing, beautifying, promoting attractiveness, or altering the appearance without affecting the body's structure or functions". (U.S. Food and Drug Administration).

Cleanliness, purification or hygiene of place, body and the surrounding environment is part of human life. To comply with this concept, physical and spiritual cleanliness of the halal provider is also a prerequisite. Besides, halal providers are required to clean their bodies and outfits. The shari'ah made cleanliness indispensable for life. In fact, the section on taharah (cleanliness) in shari'ah books is one of the imperative chapters. Oloyede explains that:

"The three basic duties that were first assigned to the prophet (Peace be upon him) centered on taharah. The first was to warn people by explaining the divine directive. The divine command necessitates glorification of Allah, demonstrated through ritual prayer, invariably purification is observed" (Oloyede, 2001).

Therefore, the term taharah is a Qur'anic concept as the Qur'an mentions it more than 31 times; and it literally refers to purify something with water and other cleansing agents (AbdulSalam, 2010). It is noteworthy to point out that the term also means beautiful manners and chastity. Taharah could also refer to inner or the outer aspects of the human (KamilMufti, 2012). The inner taharah refers maintaining, advocating or espousing the pillars of Islam and steer clear of sins. While the Outer taharah is the general body purification and this comes in the form of ablution and bath. This argument is supported by the hadith of the Prophet which reads: "If I had not been afraid of overburdening my community, I would have ordered them to use a miswak (to brush and clean their teeth) for every prayer" (Bukhari).

In other words, nadhafah which captures both the meaning of hygiene and sanitation goes hand in hand with taharah; hence, without hygiene and proper sanitation we cannot talk off halal. Hygiene in this sense refers to a set of practices associated with the preservation of healthy living (Islam, Hossain, \& Anwar, 2000). In cosmetic products, the focal point is on the hygiene of the halal provider. Sanitation on the other hand, delineates prevention of human contact with wastes or promoting non-contact with hazards. With that understanding both hygiene and sanitation are directly link to halal and taharah.

Obviously, cleanliness is a prerequisite of any spiritual or physical activities a Muslim performs; it is also an imperative condition of health and hygiene (AbdulSalam, 2010). In fact, it is part of faith in Islam. The prophet has said 
that: "Cleanliness is a part of Faith" (Muslim). In a related hadith the Prophet also said: "Islam is clean; therefore, you should keep yourselves clean, too, only the clean people can enter Paradise." (Muslim). One observes that based on this hadith, the concepts of halal and taharah cannot be separated in Islam, as halal refers to something lawful which is the only way for our deeds to be rewarded while taharah is the only means for the acceptance of act of worship. Based on this also, the two concepts are strongly linked to each other in Islam. Hence, cosmetic products should not only be halal but at the same time should be pure as well.

The concern for Muslims and the halal industry players therefore is that cosmetics and pharmaceutical products could be derived from non-halal sources. Hence, these products require halal certification (Husain, Mehad, et al., 2012). It is paramount to note that in Islam cosmetics are governed by the same shari'ah laws which regulates the rest of Muslim life; therefore, these products should be safe for consumption and at the same time should not be hazardous and harmful to human life. The halalness of these products also means the fact that is should not be obtained or directly derived from human parts or forbidden animal parts or non-halal substances.

Islam is not against the use of halal and safe cosmetics. In fact, Islam is a beautiful religion and encourages beautification. This is where cosmetics become relevant. Both the Qur'an and hadith of the Prophet consistently bring to our mind the notion of beatification in clear terms. We are in fact, encouraged to put on our best available dress and look neat and tidy at all times. We are also taught by the Qur'an and the hadith to cover our 'awrah and not to attract the shahwah of others, other than our spouse. In the Qur'an Allah says: "O Children of Adam! We have bestowed raiment upon you to cover yourselves and as an adornment and the raiment of righteousness that is better". (al-Qur'an, 7:26). In a related verse Allah reminds: "He gave them Nadratan (a light of beauty) and joy. And their recompense shall be Paradise and silken garments, because they were patient" (al-Qur'an, 76:11).

In a similar fashion, the hadith makes reference to beautification in diverse ways and approaches. From the hadith we know Allah the almighty would like to see us beautify ourselves. On this, the Prophet said: "Allah loves to see the effects of His blessing on His slave." (at-Tirmidhi). In a more related hadith the Prophet said: "No one will enter Paradise who has an atom's weight of pride in his heart." A man said, "What if a man likes his clothes to be clean, tidy and look good and his shoes to shine?" the Prophet replied, "Allah is beautiful and loves beauty. Pride means denying the truth and looking down on people". (Muslim). In a similar hadith the Prophet said: "Allah is perfect and accepts only perfect." (Muslim).

In one of the narrations it is reported that the Prophet saw Abul-Ahwas al-Jashami wearing old, tattered clothes, and asked him, "Do you have any wealth?" to which al-Jashami replied "Yes." Then the Prophet asked "What kind of wealth?" al-Jashami replied "All that Allah has given me of camels and sheeps" and the Prophet told him "Then show the generous blessings that He has bestowed upon you." (Ahmad, at-Tirmidhi and an-Nisai).

At the same time, the use of cosmetics must pass the test set by the Qur'an and the hadith and those regulations set by the Muslim countries. In Malaysia, it must comply with the Malaysian Standard MS 2200:2008 requirements. According to the standards developed by the United Arab Emirate technical committee on Halal, Najis (filth), safety and quality the concept of halal includes halalness of the product which centeres from the permissibility of the product itself.

Nonetheless, it is unfortunate to note that, the production of cosmetics has been identified with some hazardous chemicals which are linked to some serious illnesses such as cancer, reproductive harm and birth defect by the Alliance for a Healthy Tomorrow. The table below shows some of the chemical ingredients which are contained in cosmetics and associated with adverse health impact.

\begin{tabular}{|c|c|c|c|}
\hline $\begin{array}{c}\text { CHEMICAL } \\
\text { NAME }\end{array}$ & $\begin{array}{c}\text { FOUND IN THESE } \\
\text { PRODUCTS } \\
\end{array}$ & $\begin{array}{l}\text { SYMPTOMS } \\
\text { OF EXPOSURE }\end{array}$ & $\begin{array}{c}\text { POTENTIAL } \\
\text { LONG TERM EFFECTS }\end{array}$ \\
\hline Dibutyl Phthalate & Nail polish & Nausex, dizziness, eyo and skin irritation & Reproductive toxin, birth defects \\
\hline $\begin{array}{l}\text { Formaldehyde or } \\
\text { methylene glycol }\end{array}$ & $\begin{array}{l}\text { Nail hardener, nail } \\
\text { polish, keratin hair } \\
\text { straightereners }\end{array}$ & 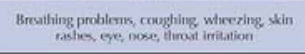 & Cancer, dermatitis \\
\hline Tolvene & $\begin{array}{l}\text { Nail polish, nail glue, } \\
\text { hair dye, wig gluo' } \\
\text { haimpiece bonding }\end{array}$ & $\begin{array}{l}\text { Dizziness, heudachers skin rashes; } \\
\text { rye, laxe, throat irritation }\end{array}$ & $\begin{array}{l}\text { Liver damage, kidhey damage, } \\
\text { birth deferts, profynicy los }\end{array}$ \\
\hline $\begin{array}{l}\text { Methyl Methacrylate } \\
\text { (MMN) }\end{array}$ & Antificial naiks & 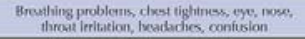 & $\begin{array}{l}\text { Loss of smest, regroducthe toxin, } \\
\text { asthua }\end{array}$ \\
\hline $\begin{array}{l}\text { Cyclopentasiloxane or } \\
\text { gyclomethicone }\end{array}$ & $\begin{array}{l}\text { Aat iron yroms } \\
\text { diembal protection } \\
\text { sprays }\end{array}$ & 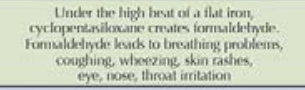 & $\begin{array}{l}\text { Formaldetrude exposure nay } \\
\text { calse cancer, dermatitis }\end{array}$ \\
\hline Styrene & $\begin{array}{l}\text { Hair extension glue, } \\
\text { lace wig ghate }\end{array}$ & Vision problents, trouble concentrating tiretiness & Cancer \\
\hline Trichlorethylene & $\begin{array}{l}\text { Hair extersion glve, } \\
\text { lace wig gluo }\end{array}$ & $\begin{array}{l}\text { Dizziness, hoadache, confusion, nauses, } \\
\text { ge and skin irrtiasion }\end{array}$ & $\begin{array}{l}\text { Liver damage, kidhey damase. } \\
\text { dermatitis, double vision }\end{array}$ \\
\hline 1,A Dioxane & $\begin{array}{l}\text { Hair extension gloe, } \\
\text { lace wig glue }\end{array}$ & Eye and nose intiation & $\begin{array}{l}\text { Cancer, liver danuge, } \\
\text { kidisy damwige }\end{array}$ \\
\hline $\begin{array}{l}\text { 2-butoxyethanol } \\
\text { of Ethyiene glycol } \\
\text { monobuty ether }\end{array}$ & Disinfectank, clesuress & Hesulartec, ore and nose irritation & Requeceluctive toxin \\
\hline
\end{tabular}


(This table is adopted from: Women's Voices for the Earth Report, 2015)

\begin{tabular}{|c|c|c|c|}
\hline $\begin{array}{c}\text { CHEMICAL } \\
\text { NAME }\end{array}$ & $\begin{array}{l}\text { FOUND IN THESE } \\
\text { PRODUCTS }\end{array}$ & $\begin{array}{c}\text { SYMPTOMS } \\
\text { OF EXPOSURE }\end{array}$ & $\begin{array}{c}\text { POTENTIAL. } \\
\text { LONG TERM EFFECTS }\end{array}$ \\
\hline $\begin{array}{l}\text { Quaternary Ammonium } \\
\text { Compounds or } \\
\text { - dimethyl benxyl } \\
\text { anmmonium chloride" }\end{array}$ & $\begin{array}{l}\text { Disinfectants and } \\
\text { cleaners }\end{array}$ & Skin, ege and nore irritation & Asthuna \\
\hline P.phenylenediamine & $\begin{array}{l}\text { Hair dyes, black beenat } \\
\text { Lattures }\end{array}$ & Sein irritation & Dermatiths \\
\hline Glyceryl thioglycolate & $\begin{array}{c}\text { Penunent was } \\
\text { solutions, "Acid perms" }\end{array}$ & Skin irritation & Dermatitis \\
\hline Ammonium persulfate & Hair bleaxh & 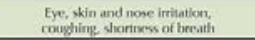 & Astme demulitis \\
\hline Ethyl methacrylate & Artificial nails & 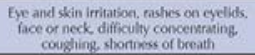 & Nothma \\
\hline Acetone & $\begin{array}{l}\text { Nail polish renover, } \\
\text { hairspersy }\end{array}$ & Eye, skin and theosat inritation, dizziness & $\begin{array}{l}\text { tyes sin and throast imication. } \\
\text { dizziness }\end{array}$ \\
\hline Acetonitrile & Nail glue remover & 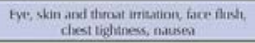 & Weakness, echaustion \\
\hline $\begin{array}{l}\text { Butyl acetate, } \\
\text { ellyil acetate or } \\
\text { isopropyl acetate }\end{array}$ & 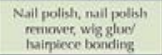 & $\begin{array}{l}\text { Eye, skin and throat irntation. } \\
\text { lewaxlaches, dieriness }\end{array}$ & $\begin{array}{l}\text { Eye, stin and throat irrication } \\
\text { dermatias }\end{array}$ \\
\hline Methacrylic acid & Nail primer, egelish glox & Skin hams, eye, nose and throst irritation & $\begin{array}{l}\text { Kidney damage, dermatitis. } \\
\text { reproductive toxin }\end{array}$ \\
\hline
\end{tabular}

Another aspect related to the use of clean and halal cosmetics is the issue of quality; it refers to the quality of the materials and ingredients used in preparing the products. Islam is religion of quality and provides comprehensive guide to quality products, therefore all substances, materials and chemicals used must be in line with Islamic teachings. In fact, the product has to be safe and safety requires high quality in every aspects. Rosita Husain and Ishak Abd. Ghani argue that:

"The product should not only be safe but also of has a high quality. But putting much effort on documentations, paperwork, and bookkeeping are not sufficient in improving the quality of these products. In improving the quality of the halal cosmetics, the concept of toyyiban must be applied. Toyyiban means highest quality in the halal concept. Therefore, to improve the quality of halal products, statistical quality control and improvement must be applied by any organization and/or manufacturer" (Rosita Husain et al, 2012).

\section{References}

Al-Qur'an al-Karim

The Hadith of the Prophet

Sharifah Zannierah Syed Marzuki Collin Michael Hall Paul William Ballantine, (2012),"Restaurant managers' perspectives on halal certification", Journal of Islamic Marketing.

Rosita Husain, Ishak Abd. Ghani, Aziz @ Fikry Mohammad and Shafie Mehad (2012) Current Practices among Halal Cosmetics Manufacturers in Malaysia, Journal of Statistical Modeling and Analytic.

Emi Normalina Omara, Harlina Suzana Jaafarb, and Muhamad Rahimi Osman (2012) Assessing Halalan-Toyyiban Food Supply Chain in the Poultry Industry International Halal Conference, PWTC, Kuala Lumpur, Malaysia, 4-5 September.

Jonathan A.J. Wilson Jonathan Liu, (2010),"Shaping the Halal into a brand?", Journal of Islamic Marketing.

Nor Ardyanti Binti Ahmad1, Tunku Nashril Bin Tunku Abaidah2 \& Mohd Helmi Bin Abu Yahya, (2013) A Study on Halal Food Awareness among Muslim Customers in Klang Valley 4th International Conference on Business and Economic Research (4th Icber 2013). Proceeding 04 - 05 March 2013 Golden Flower Hotel, Bandung, Indonesia.

Kambiz Heidarzadeh Hanzaee (2011) Intention To Halal Products In The World Markets Interdisciplinary Journal of Research in Business.

AbdulSalam, H. A. (2010). the Concept of Taharan in Islam. The Muslim World League Journal.

Ahmad, K. (2008). Management from an islamic perspective: principles and practice. Malaysia: International Islamic University Malaysia, IIUM Press.

Al-Jallad, N. (2008). The concepts of al-halal and al-haram in the Arab-Muslim culture: a translational and lexicographical study.

Islam, Z., Hossain, M. Z., \& Anwar, S. M. (2000). Hygiene and sanitation system in murang society. 26th WEDC Conference Bangladesh

KamilMufti, I. (2012). Introduction to the Purification of the Soul Why Purify the Soul? How Do You Purify Your Soul ? Islam Religion.com, (May 2012)

Oloyede M. A. (2001) Perspective in Islamic Law and Jurisprudence. Ibadan National Association of Muslim Law Students.

Omar, E. N., Jaafar, H. S., \& Osman, M. R. (2012). Assessing Halalan-Toyyiban Food Supply Chain in the Poultry Industry. International Halal Conference 2012 (INHAC), 00 (2011)

Rahman L. A. (2009), Isu Halal Tiada Penghujung, Alambaca Sdn Bhd and Pkpu, Jakim: Melaka.

UAE Technical Committee for Halal Cosmetic Issues and adopted by the ESMA (2014)

Women Voices for the Earth Report (2015) Toxic Chemical in Saloon Products worker towww.womensvoices.org. Retrieved 6 $6^{\text {th }}$ March 2015.

Yousef, D.K. (2010). Halal Food Numbers Look Tasty, Size of Global Muslim population Creates Significant Customer Base, accessed at http://gulfnews.com/business/general/halal -food-numbers- look-tasty.

Standard Procedures, (2014), on Requirements for Halal Cosmetics. UAE Technical Committee for Halal Cosmetic. 